\title{
MAX PLANCK INSTITUTE
}

FOR COMPARATIVE PUBLIC LAW

AND INTERNATIONAL LAW

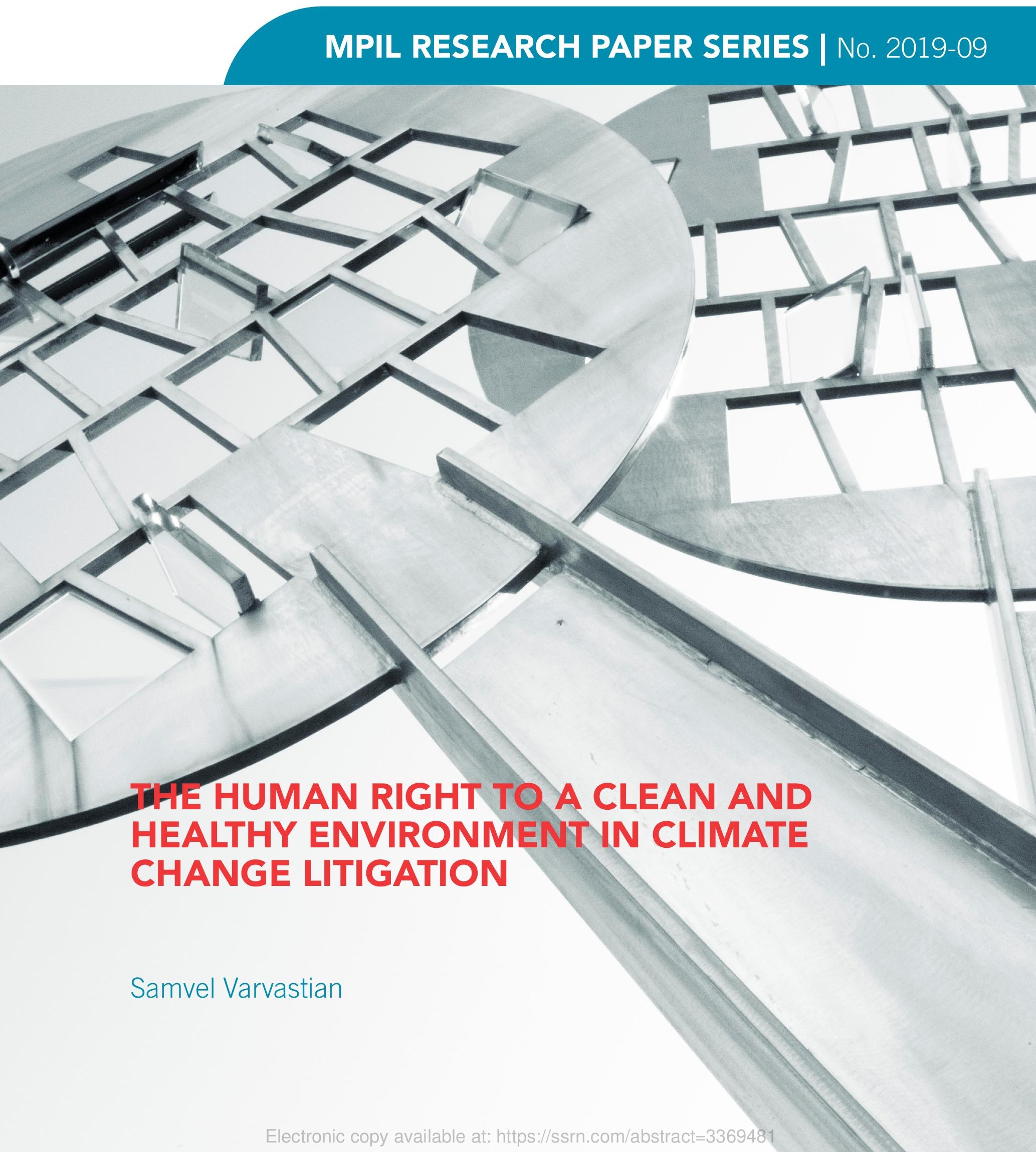




\title{
MAX PLANCK INSTITUTE
}

FOR COMPARATIVE PUBLIC LAW

AND INTERNATIONAL LAW

MPIL RESEARCH PAPER SERIES

No. 2019-09

\section{THE HUMAN RIGHT TO A}

CLEAN AND HEALTHY ENVIRONMENT IN CLIMATE CHANGE LITIGATION

\author{
AUTHOR \\ Samvel Varvastian \\ EDITORIAL DIRECTORS \\ Armin von Bogdandy, Anne Peters \\ EDITOR-IN-CHIEF \\ Raffaela Kunz \\ TECHNICAL ASSISTANCE \\ Verena Schaller-Soltau \\ Angelika Schmidt
}




\section{ABSTRACT}

This paper discusses a particular field of climate change law: climate change litigation based on claims stemming from the right to a clean and healthy environment under national and international human rights law. This field is coming under increased scrutiny of both legal scholars and practitioners. While the share of rights-based climate cases within the global body of climate change litigation is still very insignificant, a number of such cases have already been heard by courts all across the globe. The initial assessment of the existing case-law allows for cautious optimism that the use of rights-based claims, notably the right to a clean and healthy environment under national and/or international law, is justified and can yield at least some positive results.

\section{KEYWORDS:}

Climate change, litigation, courts, human rights, right to a clean and healthy environment, international law, constitutional law, public trust doctrine 


\section{The Human Right to a Clean and Healthy Environment in Climate Change Litigation}

\section{Samvel Varvastian*}

\section{Introduction}

Concluding her analysis on the climate law state-of-the-art back in 2008, Jacqueline Peel observed: "The diversity of legal developments with respect to climate change [...] amply makes the case that the last few years have witnessed the emergence of a new legal discipline, that of climate change law. [...] The innovativeness of the case law in particular - decided as it was in the absence of a national regulatory system for climate change - provides an encouraging indication of the law's capacity to evolve and adapt to deal with this new environmental problem." ${ }^{11}$ Ten years have passed and in their span, the world has witnessed a boom in climate change litigation with plaintiffs invoking all kinds of legal strategies. ${ }^{2}$ One of the boldest strategies employed by the plaintiffs has been the targeting of the very ambition of national climate policies and using human rights law as the foundation of their claims. Several of these cases have resulted in breakthrough victories.

Why is judicial intervention and innovativeness important within this field? To put it simply, climate change is one of the most, or perhaps even the most stressing problem of our time; therefore, dealing with it requires an "all-hands-on-deck" approach, ${ }^{3}$ mobilizing action well beyond the shambling international negotiations. Fortunately, the need for global action is wellunderstood and nearly-universally acknowledged. ${ }^{4}$ But then comes the hard part: taking that action. At the time of writing, the world has crossed yet another dangerous line, with the Mauna

\footnotetext{
* PhD Researcher at the School of Law and Politics, Cardiff University. I am grateful to Anna Grear and Valerie Fogleman for their support during the production of this paper. I would also like to thank Pedro Villarreal as well as Stefania Negri and Stéphanie Dagron and other organizers and participants of the conference "Health and the Environment in International Law: Actors, Norms and Responsibilities" held on October 17-18, 2018, in Max Planck Institute for Comparative Public Law and International Law, Heidelberg, for their valuable feedback on this paper. I am also grateful to Harro van Asselt for his comments on the earlier draft of this paper.

${ }^{1}$ Jacqueline Peel, Climate Change Law: the Emergence of a New Legal Discipline, 32(3) Melbourne University Law Review 922 (2008), at 977-978.

${ }^{2}$ Comprehensive databases of global climate change litigation are maintained by Sabin Center for Climate Change Law at Columbia Law School (available at http://climatecasechart.com/) and Grantham Research Institute on Climate Change and the Environment at London School of Economics and Political Science (available at http://www.lse.ac.uk/GranthamInstitute/climate-change-laws-of-the-world/).

${ }^{3}$ Remi Moncel and Harro van Asselt, All hands on deck! Mobilizing climate change action beyond the UNFCCC, 21(3) Review of European, Comparative \& International Environmental Law 163 (2012), at 164.

${ }^{4}$ For example, the Paris Agreement, which "represents the most ambitious outcome possible in a deeply discordant political context." Lavanya Rajamani, Ambition and differentiation in the 2015 Paris Agreement: Interpretative possibilities and underlying politics, International \& Comparative Law Quarterly 65.2 (2016): 493-514.
} 
Loa Observatory in Hawaii reporting that atmospheric concentrations of carbon dioxide - a powerful greenhouse gas (GHG) and one of the main "culprits" in anthropogenically-driven climate change ${ }^{5}$ - averaged above 410 parts per million ${ }^{6}$ throughout an entire month for the very first time in the history of monitoring. ${ }^{7}$ Apart from the fact that this is certainly not good news for the planet's climate, it is most troubling that such ominous reports are now practically routine. Considering that the international awareness of climate change and the legal measures dedicated to tackle it are nearly three decades old, ${ }^{8}$ one cannot help wondering, why the situation is actually getting worse.

At this critical juncture, the development of climate change law might be expected to focus on the most practical matters, employing solution-oriented approaches and learning from other areas. This paper discusses one particular field of climate change law - climate change litigation based on claims stemming from the right to a clean and healthy environment under national and international human rights law ${ }^{9}$ - which is coming under increased scrutiny of both legal scholars and practitioners. Although litigation may not necessarily be a panacea to climate crisis, the development of this particular field is important in building a multi-level workable response to climate change. ${ }^{10}$

\section{Climate Change Litigation: A Panoply of Theory and Practice}

Climate change has been a widely discussed topic over the last three decades and has attracted an ever-growing public attention. Although some individuals, including politicians, still face the idea of anthropogenically-driven climate change with a degree of skepticism or even outward

\footnotetext{
${ }^{5}$ See, in general, IPCC, 2014: Climate Change 2014: Synthesis Report. Contribution of Working Groups I, II and III to the Fifth Assessment Report of the Intergovernmental Panel on Climate Change [Core Writing Team, R.K. Pachauri and L.A. Meyer (eds.)]. IPCC, Geneva, Switzerland, p. 151 ff., p 4.

${ }^{6}$ The current concentration of carbon dioxide in the atmosphere is about $0.04 \%$, having risen from pre-industrial levels of less than $0.03 \%$ ( 280 parts per million).

${ }^{7}$ Chris Mooney, Earth's atmosphere just crossed another troubling climate change threshold, The Washington Post, 3 May 2018. https://www.washingtonpost.com/news/energy-environment/wp/2018/05/03/earths-atmosphere-justcrossed-another-troubling-climate-change-threshold/?noredirect=on\&utm_term=.1f329faaed0f

${ }^{8}$ Thus, at the intergovernmental level, the issue of climate change emerged in the late 1980s, marking the period of agenda-setting in what was to become the UN climate regime. See Daniel Bodansky, Jutta Brunnée and Lavanya Rajamani, International Climate Change Law (Oxford: Oxford University Press, 2017), p. 99.

9 The United Nations Environment Programme describes the following three main dimensions of the interrelationship between human rights and environmental protection: (i) the environment as a prerequisite for the enjoyment of human rights (implying that human rights obligations of States should include the duty to ensure the level of environmental protection necessary to allow the full exercise of protected rights); (ii) certain procedural human rights, especially access to information, participation in decision-making, and access to justice in environmental matters, as essential to good environmental decision-making (implying that human rights must be implemented in order to ensure environmental protection); and (iii) the right to a safe, healthy and ecologicallybalanced environment as a human right in itself (noting, though, that this approach has been debated). See <http://web.unep.org/divisions/delc/human-rights-and-environment>.

${ }^{10}$ On the importance of courts weighing in on climate change see, e.g., Brian J. Preston, The Contribution of the Courts in Tackling Climate Change, 28(1) Journal of Environmental Law 11 (2016); Hari M. Osofsky, The Continuing Importance of Climate Change Litigation, Climate Law 1 (2010): 3-29.
} 
denial, ${ }^{11}$ the general consensus among scientists ${ }^{12}$ and universal recognition by the 1992 United Nations Framework Convention on Climate Change ${ }^{13}$ as well as the subsequent international treaties, and globally emerging climate legislation at national level ${ }^{14}$ make a more than enough strong case in favor of recognizing the reality of climate change and humanity's responsibility for contributing to it.

Unfortunately, the recognition of human economic activity - primarily energy generation by means of fossil fuel burning - as a factor significantly influencing the climate, has fallen short of any concrete action scheme that could successfully mitigate this process. ${ }^{15}$ In the wake of this regulatory failure, climate change litigation - a new and alternative pathway to climate change governance - has been steadily making its way into global arena. ${ }^{16}$ Serving, at least in part, as a regulatory gap-filler, it has been pushing the boundaries of traditionally passive, or altogether absent climate policy for the last decade. ${ }^{17}$ Although scholarly studies have identified and

${ }^{11}$ See, for example, Sander Van der Linden et al., Inoculating the public against misinformation about climate change, Global Challenges 1.2 (2017): 1600008.

${ }^{12}$ Various studies have estimated that approximately $97 \%$ of publishing climate scientists share the view that human activities are the cause of recent global warming. See: John Cook et al., Quantifying the consensus on anthropogenic global warming in the scientific literature, Environmental research letters 8.2 (2013): 024024; John Cook et al., Consensus on consensus: a synthesis of consensus estimates on human-caused global warming, Environmental Research Letters 11.4 (2016): 048002.

${ }_{13}$ United Nations, United Nations Framework Convention on Climate Change, Bonn, Germany: UNFCCC Secretariat, 1992, http://unfccc.int/resource/docs/convkp/conveng.pdf

${ }^{14}$ See Michal Nachmany and Joana Setzer, Global Trends in Climate Change Legislation and Litigation: 2018 Snapshot (London School of Economics and Political Science, 2018).

${ }^{15}$ Thus, recent anthropogenic GHG emissions are the highest in history (IPCC, at 44) and the gap between what governments have promised to do and the total level of actions they have undertaken to date remains substantial, while both the current policy and pledge trajectories lie well above emissions pathways consistent with the Paris Agreement long-term temperature goal (see, e.g., <https://climateactiontracker.org/>). For a discussion on difficulties surrounding climate change governance see: Richard J. Lazarus, Super Wicked Problems and Climate Change: Restraining the Present to Liberate the Future, Cornell Law Review 94 (2009): 1153; Elizabeth Fisher, Eloise Scotford, and Emily Barritt, The Legally Disruptive Nature of Climate Change, Modern Law Review 80.2 (2017): 173-201.

${ }^{16}$ Hari M. Osofsky, The Continuing Importance of Climate Change Litigation, Climate Law 1 (2010): 3-29; Harro van Asselt, Michael Mehling, and Clarisse Kehler Siebert, The Changing Architecture of International Climate Change Law, in Research Handbook on Climate Change Mitigation Law, eds. Geert Van Calster, Wim Vandenberghe and Leonie Reins (Edward Elgar, 2015): 24.

${ }^{17}$ One of the most illustrative examples is Massachusetts $v$. EPA case, the very first climate change case that has made all the way to the US Supreme Court. In this case, the plaintiffs, including the state of Massachusetts as well as other states along with local governments and private organisations, alleged that the US Environmental Protection Agency abdicated its responsibility under the federal air quality legislation to regulate automobile GHG emissions. In a historic move, the Supreme Court acknowledged the existence of a causal link between GHG emissions and climate change, and the impact of climate change on the environment, holding that the widely shared nature of such an injury does not diminish the interest of concrete parties and emphasizing that the existence of other major GHG emitters like China and India, should not preclude the US agency from its regulatory duty, even if the latter by itself is unable to solve the global problem, since "[a] reduction in domestic emissions would slow the pace of global emissions increases, no matter what happens elsewhere." Massachusetts v. E.P.A 549 U.S. 497 (2007). Notably, in his dissenting opinion, Chief Justice Roberts (joined by three other justices) disagreed with such an interpretation, claiming that there were critical difficulties in demonstrating causation and redressability that rendered the case nonjusticiable. It must be observed that in the years to follow, the US courts have not shown consistency when dealing with the issue of causation and redressability. See Samvel Varvastian, Access to Justice in Climate Change 
classified climate cases based on various criteria, so far, litigation revolving around the environmental impact assessment legislation and air quality legislation has been the dominating type of climate cases. ${ }^{18}$ Such litigation has been used with mixed success, ${ }^{19}$ mostly to challenge the authorization of fossil fuel development and operations as well as action with regard to GHG emissions standards. ${ }^{20}$ It is true, though, that in spite of the constantly growing number of climate cases, their jurisdictional distribution has been very uneven; thus, only a few jurisdictions predominantly pertaining to the common law legal system (most notably the US and Australia) have established a body of relevant case-law so far. ${ }^{21}$ In those jurisdictions, litigation has become an important feature of climate governance, ${ }^{22}$ regardless of numerous challenges and setbacks that plaintiffs have encountered. ${ }^{23}$

Furthermore, with the ever-expanding body of climate cases, ${ }^{24}$ the topic of climate change litigation has attracted significant attention of legal scholars, most notably from jurisdictions with rich climate change litigation traditions. ${ }^{25}$ Following the first relatively large wave of climate cases in the mid 2000s and up to the time of the adoption of the Paris Agreement, ${ }^{26}$ a number of fundamental works have been published, reflecting the obvious need to classify such cases and clarify their role within the emerging field of climate change law. ${ }^{27}$ These pioneering works played a huge role in paving the way for a new generation of scholarship. Thus, in recent years, scholarly works have begun focusing on more specific areas of climate change litigation

Litigation from a Transnational Perspective: Private Party Standing in Recent Climate Cases, in J. Jendrośka and M. Bar (eds), Procedural Environmental Rights: Principle $X$ of the Rio Declaration in Theory and Practice (Cambridge: Intersentia, 2017).

${ }^{18}$ See: Markell, D. and Ruhl, J. B. (2012) An Empirical Assessment of Climate Change in the Courts: A New Jurisprudence or Business as Usual?, Florida Law Review 64(1), pp. 15-86; Lin, J. (2012) Climate change and the courts, Legal studies, 32(1), pp. 35-57; Peel, J. and Osofsky, H. M. (2013) Climate Change Litigation's Regulatory Pathways: A Comparative Analysis of the United States and Australia, Law and Policy 35(3), pp. 150-183.

${ }^{19}$ Sabrina McCormick et al. Strategies in and outcomes of climate change litigation in the United States, Nature Climate Change (2018): 1.

${ }^{20}$ Samvel Varvastian, Access to Justice in Climate Change Litigation from a Transnational Perspective: Private Party Standing in Recent Climate Cases, 447-454, in J. Jendrośka and M. Bar (eds), Procedural Environmental Rights: Principle X of the Rio Declaration in Theory and Practice (Cambridge: Intersentia, 2017).

${ }^{21}$ See: J. Peel \& H. M. Osofsky, Climate Change Litigation: Regulatory Pathways to Cleaner Energy, 2015, pp. 1618; M. Wilensky, Climate Change in the Courts: An Assessment of Non-US Climate Litigation, Duke Environmental Law \& Policy Forum 2015 (26), p. 131.

${ }^{22}$ J. Peel \& H. M. Osofsky, Climate Change Litigation's Regulatory Pathways: A Comparative Analysis of the United States and Australia, Law \& Policy 2013 (35), at 175.

${ }^{23}$ J. Peel \& H. M. Osofsky, Climate Change Litigation: Regulatory Pathways to Cleaner Energy, 2015, pp. $266-267$.

${ }^{24}$ The databases at Sabin Center and LSE reflect the steady rise in the number of such cases.

${ }^{25}$ See, for instance, Elizabeth Fisher, Climate Change Litigation, Obsession and Expertise: Reflecting on the Scholarly Response to Massachusetts v. EPA, 35(3) Law \& Policy 236 (2013).

26 Paris Agreement under the United Nations Framework Convention on Climate Change, CFCCC/CP/2015/L.9/Rev.1.

${ }^{27}$ It must be observed that these works have often applied different methodologies and terminology. See David Markell and J. B. Ruhl, An Empirical Assessment of Climate Change in the Courts: A New Jurisprudence or Business as Usual?, 64(1) Florida Law Review 15 (2012); Jolene Lin, Climate Change and the Courts, 32(1) Legal Studies 35 (2012); Meredith Wilensky, Climate Change in the Courts: an Assessment of non-US Climate Litigation, 26(1) Duke Environmental Law \& Policy Forum 131 (2015); Jacqueline Peel and Hari M. Osofsky, Climate Change Litigation: Regulatory Pathways to Cleaner Energy (Cambridge: Cambridge University Press, 2015). 
(including the basis for different claims) and its application as well as drawing parallels to other forms of environmental and health litigation. For example, these include: the role of public health claims in climate cases ${ }^{28}$ the relevance of experience in tobacco liability litigation and other forms of litigation revolving around nationwide threats brought by states and cities to climate change liability lawsuits against major fossil fuel companies ${ }^{29}$ litigation against private entities (fossil fuel companies) ${ }^{30}$ prospective international climate damages litigation ${ }^{31}$ and litigation before international courts, ${ }^{32}$ the nascent interpretation of international environmental/climate change law principles in national climate change litigation; ${ }^{33}$ the potential of developing extreme event attribution science to help overcome causation challenges faced by climate plaintiffs; ${ }^{34}$ the use of climate change litigation as a critical tool in shaping public discourse and advancing the climate movement; ${ }^{35}$ the importance of considering "smaller"

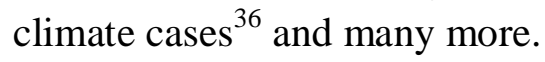

Given the fact that climate change has already affected and will continue to affect an array of human rights, including the right to health, housing, food and water and, as the impact of climate change worsens, even the right to life, the prospective violation of these rights by continuing with "business as usual" climate policy is obvious. ${ }^{37}$ Therefore, it is quite fitting that litigation

\footnotetext{
${ }^{28}$ Sabrina McCormick et al., The Role of Health in Climate Litigation, 108(S2) American Journal of Public Health S104 (2018).

${ }^{29}$ Christine Shearer, On Corporate Accountability: Lead, Asbestos, and Fossil Fuel Lawsuits, 25(2) New Solutions: A Journal of Environmental and Occupational Health Policy 172 (2015); Martin Olszynski, Sharon Mascher and Meinhard Doelle, From Smokes to Smokestacks: Lessons from Tobacco for the Future of Climate Change Liability, 30(1) Georgetown Environmental Law Review 1 (2017); Wes E. Henricksen, Peddling Ignorance: A New Falsity Standard for Scientific Knowledge Fraud Cases, 86(2) UMKC Law Review 295 (2017); Sarah L. Swan, Plaintiff Cities, 71(4) Vanderbilt Law Review 1227 (2018).

${ }^{30}$ Geetanjali Ganguly, Joana Setzer and Veerle Heyvaert, If at first you don't succeed: suing corporations for climate change, 38(4) Oxford Journal of Legal Studies 841 (2018).

${ }^{31}$ Michael Byers, Kelsey Franks, and Andrew Gage, The Internationalization of Climate Damages Litigation, 7(2) Washington Journal of Environmental Law \& Policy 264 (2017).

${ }^{32}$ Philippe Sands, Climate Change and the Rule of Law: Adjudicating the Future in International Law, 28(1) Journal of Environmental Law 19 (2016); Daniel Bodansky, The Role of the International Court of Justice in Addressing Climate Change: Some Preliminary Reflections, 49 Arizona State Law Journal 689 (2017).

${ }^{33}$ Tracy Bach, Human Rights in a Climate Changed World: The Impact of COP21, Nationally Determined Contributions, and National Courts, 40(3) Vermont Law Review 561 (2016); Patrícia G. Ferreira, Common but Differentiated Responsibilities in the National Courts: Lessons from Urgenda v. The Netherlands, 5(2) Transnational Environmental Law 329 (2016); Esmeralda Colombo, Enforcing International Climate Change Law in Domestic Courts: A New Trend of Cases for Boosting Principle 10 of the Rio Declaration, 35(1) UCLA Journal of Environmental Law \& Policy 98 (2017); Cordelia Christiane Bähr et al., KlimaSeniorinnen: lessons from the Swiss senior women's case for future climate litigation, Journal of Human Rights and the Environment 9.2 (2018): 194-221.

${ }^{34}$ Sophie Marjanac and Lindene Patton, Extreme weather event attribution science and climate change litigation: an essential step in the causal chain?, 36(3) Journal of Energy \& Natural Resources Law 265 (2018).

${ }^{35}$ Grace Nosek, Climate Change Litigation and Narrative: How to Use Litigation to Tell Compelling Climate Stories, 42(3) William \& Mary Environmental Law and Policy Review 733 (2018).

${ }^{36}$ Kim Bouwer, The Unsexy Future of Climate Change Litigation, 30(3) Journal of Environmental Law 483 (2018).

${ }^{37}$ See Report of the Special Rapporteur on the Issue of Human Rights Obligations relating to the Enjoyment of a Safe, Clean, Healthy and Sustainable Environment, UN Doc. A/HRC/31/52 (1 February 2016); Understanding Human Rights and Climate Change. Submission of the Office of the High Commissioner for Human Rights to the
} 
targeting the persisting governmental inertia with regard to climate change policy could employ a rights-based approach, for instance, by invoking the right to a clean and healthy environment. The question, however, is whether such claims could prove viable in a courtroom. While the share of rights-based climate cases within the global body of climate change litigation is still very insignificant, a number of such cases have already been heard by courts all across the globe. The initial assessment of the existing case-law allows for cautious optimism that the use of rights-based claims, notably, the right to a clean and healthy environment under national and/or international law, is justified and can yield at least some positive results.

\section{Rights-based Climate Change Litigation: The Right to a Clean and Healthy Environment}

The impact of climate change on human rights is well-documented in legal scholarship ${ }^{38}$ and beyond. ${ }^{39}$ The relevance of considering human rights when dealing with climate change is also explicitly referred to in the Paris Agreement, ${ }^{40}$ for the first time in the history of binding multilateral climate treaties. ${ }^{41}$ Still, the appearance of rights-based climate cases on the global stage of climate change litigation has been rather slow, despite the fact that the first attempts to use rights-based claims in such cases date back to the mid-2000s.

The most notable example of this early litigation is Gbemre v. Shell case in Nigeria. ${ }^{42}$ The petitioner, representing the Iwherekan community, alleged that the oil production activities (gas

21st Conference of the Parties to the United Nations Framework Convention on Climate Change (26 November 2015) 〈http://www.ohchr.org/Documents/Issues/ClimateChange/COP21.pdf>

${ }^{38}$ See, for example, John H. Knox, Linking Human Rights and Climate Change at the United Nations, 33(2) Harvard Environmental Law Review 477 (2009); Stephen Humphreys (ed.), Human Rights and Climate Change (Cambridge: Cambridge University Press, 2010); Anna Grear and Louis J Kotzé (eds), Research Handbook on Human Rights and the Environment (Cheltenham: Edward Elgar Publishing, 2015); John H. Knox, Human Rights Principles and Climate Change in The Oxford Handbook of International Climate Change Law, edited by Kevin R. Gray, Cinnamon Piñon Carlarne and Richard Tarasofsky (Oxford: Oxford University Press, 2016); Daniel Bodansky, Jutta Brunnée and Lavanya Rajamani, International Climate Change Law (Oxford: Oxford University Press, 2017); Sam Adelman, Human Rights in the Paris Agreement: Too Little, Too Late, 7(1) Transnational Environmental Law 17 (2018); Sébastien Duyck, Sébastien Jodoin and Alyssa Johl (eds.), Routledge Handbook of Human Rights and Climate Governance (Abingdon: Routledge, 2018); John H. Knox and Ramin Pejan (eds.), The Human Right to a Healthy Environment (Cambridge: Cambridge University Press, 2018); Journal of Human Rights and the Environment (March 2010 - ), Edward Elgar Publishing, ISSN: 17597188.

${ }^{39}$ Report of the Special Rapporteur on the Issue of Human Rights Obligations relating to the Enjoyment of a Safe, Clean, Healthy and Sustainable Environment, UN Doc. A/HRC/31/52 (1 February 2016); Understanding Human Rights and Climate Change. Submission of the Office of the High Commissioner for Human Rights to the 21st Conference of the Parties to the United Nations Framework Convention on Climate Change (26 November 2015) <http://www.ohchr.org/Documents/Issues/ClimateChange/COP21.pdf>

${ }^{40}$ The Preamble to the Paris Agreement states the following: "Acknowledging that climate change is a common concern of humankind, Parties should, when taking action to address climate change, respect, promote and consider their respective obligations on human rights, the right to health, the rights of indigenous peoples, local communities, migrants, children, persons with disabilities and people in vulnerable situations and the right to development, as well as gender equality, empowerment of women and intergenerational equity".

${ }^{41}$ Adelman, supra note.

42 Jonah Gbemre v. Shell, NNPC and AGF, No FHC/B/CS/53/05 (Federal High Court, 2005). 
flaring) of the respondents (Shell Petroleum Development Company of Nigeria Ltd and the Nigerian National Petroleum Corporation) violated his rights to life and dignity, enshrined in the Nigerian Constitution and the African Charter on Human and Peoples' Rights, because they adversely affected his life and health as well as the local environment. The Federal High Court of Nigeria agreed with the petitioner and stressed that the above-mentioned constitutionally guaranteed rights, reinforced by international human rights law, "inevitably include the rights to a clean, poison-free, pollution-free, and healthy environment," and that the respondents' practice "to flare gas in the course of their oil exploration and production activities in the applicant's community is a gross violation of their fundamental right to life (including healthy environment) and dignity of the human person as enshrined in the [Nigerian] constitution." 43 True enough, it was observed that despite its landmark nature, the decision had a number of weaknesses, ${ }^{44}$ and did not halt the practice of gas flaring in Nigeria. ${ }^{45}$

Meanwhile another early attempt to use international human rights law, the Inuit petition to the Inter-American Commission on Human Rights seeking relief from human rights violations resulting from the impacts of global warming and climate change caused by acts and omissions of the United States, ${ }^{46}$ was rejected, although, as suggested by some leading climate law scholars, "it probably has had some indirect regulatory influence, particularly in terms of changing norms and values through increasing the public profile of Arctic climate change impacts." $" 47$

Considering the modern day rights-based climate change litigation, a distinction based on the source of human rights claims, may be drawn between the US and non-US cases. In the United States a rights-based approach has been systematically employed in climate change litigation since 2011, also known as atmospheric trust litigation. ${ }^{48}$ The cases belonging to this category are the result of a nationwide campaign, which seeks judicial recognition of the fact that the planet's

\footnotetext{
${ }^{43}$ Ibid., pp. 29-30.

44 See Kaniye SA Ebeku, Constitutional right to a healthy environment and human rights approaches to environmental protection in Nigeria: Gbemre v. Shell revisited, Review of European Community \& International Environmental Law 16.3 (2007): 312-320.

${ }^{45}$ See Wilensky, p. 143.

${ }^{46}$ Petition to the Inter-American Commission on Human Rights Seeking Relief from Violations Resulting from Global Warming Caused by Acts and Omissions of the United States (7 December 2005) (summary of the petition is available at $\mathrm{http} / / / \mathrm{www}$.inuitcircumpolar.com/uploads/3/0/5/4/30542564/finalpetitionsummary.pdf. The petitioners requested the Commission to recommend that the United States adopt mandatory measures to limit its GHG emissions, consider the impacts of GHG emissions on the Arctic in evaluating all major government actions, establish and implement a plan to protect Inuit culture and resources and provide assistance necessary for Inuit to adapt to the impacts of climate change that cannot be avoided. See also Hari M. Osofsky, Inuit Petition as a Bridge? Beyond Dialectics of Climate Change and Indigenous Peoples' Rights, American Indian Law Review 31 (2007): 675 .

47 Jacqueline Peel and Hari M. Osofsky, Climate Change Litigation's Regulatory Pathways: A Comparative Analysis of the United States and Australia, Law \& Policy 35.3 (2013): p. 160.

${ }^{48}$ See Samvel Varvastian, A Natural Resource Beyond the Sky: Invoking the Public Trust Doctrine to Protect the Atmosphere from Greenhouse Gas Emissions, 121-135, in Sustainable Management of Natural Resources: Legal Instruments and Approaches, eds. Helle Tegner Anker \& Birgitte Egelund Olsen (Cambridge: Intersentia, 2018).
} 
atmosphere is a natural resource covered by the common law public trust doctrine and the government is under an obligation to protect it from dangerous GHG emissions. ${ }^{49}$ The atmospheric trust litigation challenges the governmental climate policy at state and/or federal level, and as the public trust doctrine is in some cases enshrined in constitutional law, ${ }^{50}$ its interpretation with regard to the atmosphere as well as to the right to a clean and healthy environment often has constitutional ramifications. ${ }^{51}$

There are several notable examples of this line of cases, all having a constitutional background. One is Funk v. Wolf in Pennsylvania, where the petitioners sought the court's order to require the respondents (the Governor of Pennsylvania, Pennsylvania Department of Environmental Protection and other state officials and agencies) to carry out various studies, investigations, or any other analyses to determine the impact of climate change on the rights established in the constitutional provision, commonly referred to as the Environmental Rights Amendment, and to establish a comprehensive regulatory scheme to reduce GHG emissions, thus satisfying their constitutional obligations. ${ }^{52}$ Importantly, the constitutional provision that the petitioners referred to, explicitly granted environmental human rights ${ }^{53}$ by providing that

"The people have a right to clean air, pure water, and to the preservation of the natural, scenic, historic and esthetic values of the environment. Pennsylvania's public natural resources are the common property of all the people, including generations yet to come. As trustee of these resources, the Commonwealth shall conserve and maintain them for the benefit of all the people." 54

The interpretation of this provision in earlier case-law by the state supreme court seemed to favour the plaintiffs. ${ }^{55}$ However, in Funk $v$. Wolf the court used a narrow interpretation of this

\footnotetext{
${ }^{49}$ The public trust doctrine requires government to hold vital natural resources in trust for the public beneficiaries, thus protecting those resources from monopolization or destruction by private interests. See Mary Christina Wood and Charles W. Woodward IV, Atmospheric Trust Litigation and the Constitutional Right to a Healthy Climate System: Judicial Recognition at Last, 6(2) Washington Journal of Environmental Law and Policy 633 (2016), at 647-648.

${ }^{50}$ See Alexandra B. Klass, The Public Trust Doctrine in the Shadow of State Environmental Rights Laws: A Case Study, 45(2) Environmental Law 431 (2015); Sam Kalen, An Essay: An Aspirational Right to a Healthy Environment, 34(2) UCLA Journal of Environmental Law \& Policy 156 (2016).

${ }^{51}$ See Michael C. Blumm and Mary Christina Wood, No Ordinary Lawsuit: Climate Change, Due Process, and the Public Trust Doctrine, 67(1) American University Law Review 1 (2017).

${ }^{52}$ Funk v. Wolf, 144 A.3d 228 ( Pa.Cmwlth. 2016). See also the commentary of this case in Samvel Varvastian, Climate Change and the Constitutional Obligation to Protect Natural Resources: The Pennsylvania Atmospheric Trust Litigation, (2017) Climate Law 7(2-3), 209-226.

${ }^{53}$ See Robinson Twp., Washington Cnty. v. Commonwealth , 83 A.3d 901, at 962-963 (Pa. 2013): "The decision to affirm the people's environmental rights in a Declaration or Bill of Rights, alongside political rights, is relatively rare in American constitutional law. In addition to Pennsylvania, Montana and Rhode Island are the only other states of the Union to do so."

${ }^{54} \mathrm{~Pa}$. Const. Art. 1, § 27. The amendment was adopted on 18 May 1971.

${ }^{55}$ With regard to the special place of the provision in the context of other state constitutions, the Supreme Court of Pennsylvania stated the following: "That Pennsylvania deliberately chose a course different from virtually all of its sister states speaks to the Commonwealth's experience of having the benefit of vast natural resources whose virtually unrestrained exploitation, while initially a boon to investors, industry, and citizens, led to destructive and lasting consequences not only for the environment but also for the citizens' quality of life. Later generations paid and
} 
provision, stating that it does not provide absolutist priority to the environmental rights and instead, requires from the policymakers to weigh conflicting environmental and social concerns in making their decisions. ${ }^{56}$ Therefore, the court concluded that the petitioners did not have a clear right to have the respondents perform the requested actions. ${ }^{57}$

In another similar case, Foster v. Ecology, the petitioners requested the government of the Washington state to implement rules that would ensure carbon dioxide emissions are reduced at levels scientifically required to protect the oceans from acidification and the climate system from further disruption. ${ }^{58}$ The plaintiffs based their claims on the public trust doctrine under state constitution. ${ }^{59}$ And although the Superior Court of Washington did not explicitly expand the state public trust doctrine to encompass the atmosphere, it acknowledged that the planet's climate forms an integral part of the global environment, ${ }^{60}$ thus its protection should fall within the scope of environmental human rights, concluding that "if ever there were a time to recognize through action [the] right to preservation of a healthful and pleasant atmosphere, the time is now."61 Conversely though, another judge of the same court refused to back this position in a follow-up case Aji P. v. State of Washington, stating that there is no fundamental constitutional right "to a healthful and pleasant environment, which includes a stable climate system that sustains human life and liberty", to be found within state constitution. ${ }^{62}$ Moreover, the judge relied on an opinion in a case concerning local environmental contamination, where a federal court in Michigan stated that "whenever federal courts have faced assertions of fundamental rights to a 'healthful environment' or to freedom from harmful contaminants, they have invariably rejected those claims.",63

continue to pay a tribute to early uncontrolled and unsustainable development financially, in health and quality of life consequences, and with the relegation to history books of valuable natural and esthetic aspects of our environmental inheritance. The drafters and the citizens of the Commonwealth who ratified the Environmental Rights Amendment, aware of this history, articulated the people's rights and the government's duties to the people in broad and flexible terms that would permit not only reactive but also anticipatory protection of the environment for the benefit of current and future generations." Robinson Twp., 83 A.3d at 963.

${ }^{56}$ Funk v. Wolf, 144 A.3d, at 233-234.

${ }^{57}$ Ibid., at 250-251. In other words, in interpreting the abovementioned constitutional provision, the court followed the approach of some other US courts, interpreting constitutional provisions as non-self-executing and thus barring the plaintiffs from invoking it due to the absence of "precise regulations and standards governing the topic". See on this Dinah Shelton, Complexities and Uncertainties in Matters of Human Rights and the Environment: Identifying the Judicial Role, in John H. Knox and Ramin Pejan (eds.), The Human Right to a Healthy Environment (Cambridge: Cambridge University Press, 2018), p. 101.

${ }^{58}$ Foster v. Wash. Dep't of Ecology, No. 14-2-25295-1 SEA, 2015 WL 7721362, at 1 (Wash. Super. Ct. 2015).

${ }^{59}$ Ibid., at 3-4.

${ }^{60}$ Judge Hill described the link between the atmosphere and other natural resources in the following way: "the navigable waters and the atmosphere are intertwined and to argue a separation of the two, or to argue that GHG emissions do not affect navigable waters is nonsensical" (at 8).

${ }^{61}$ Ibid.

${ }^{62}$ Aji P. v. State of Washington, No. 18-2-04448-1, 2018 WL 3978310. At 7 (Wash. Super. Ct. 2018).

${ }^{63}$ Lake v. City of Southgate, No. 16-10251, WL 767879 (slip op.) (E.D. Mich. 2017). 
It is important to note that this position, as observed by both Michigan and Washington state courts themselves, ${ }^{64}$ is not exactly accurate, since it contradicts the 2016 findings in the ongoing atmospheric trust litigation at the federal level, Juliana $v$. United States. ${ }^{65}$ The case was brought by a group of children against the US President and a number of federal agencies, challenging numerous decisions taken by the defendants, such as "whether and to what extent to regulate [carbon dioxide] emissions from power plants and vehicles, whether to permit fossil fuel extraction and development to take place on federal lands, how much to charge for use of those lands, whether to give tax breaks to the fossil fuel industry, whether to subsidize or directly fund that industry, whether to fund the construction of fossil fuel infrastructure such as natural gas pipelines at home and abroad, whether to permit the export and import of fossil fuels from and to the US, and whether to authorize new marine coal terminal projects." 66 According to the plaintiffs, the defendants have known for more than fifty years that carbon dioxide produced by burning fossil fuels was destabilizing the climate system, significantly endangering the plaintiffs, yet despite that knowledge, they exercised the sovereign authority over the country's atmosphere and fossil fuel resources in such a way that permitted, encouraged, and enabled continued exploitation, production and combustion of fossil fuels, thus deliberately allowing atmospheric concentrations of carbon dioxide to escalate to unprecedented levels. ${ }^{67}$ The plaintiffs asserted that the defendants' decisions have substantially caused the planet to warm and the oceans to rise, thus drawing a direct causal line between defendants' policy choices and floods, food shortages, destruction of property, species extinction, and various other harms. ${ }^{68}$ Accordingly, the plaintiffs based their lawsuit on constitutional grounds ${ }^{69}$ as well as the public trust doctrine. And the federal judge Ann Aiken, who heard the case, made history, by stating that exercising "reasoned judgment," there is "no doubt that the right to a climate system capable of sustaining human life is fundamental to a free and ordered society."70

Meanwhile, outside of the United States, rights-based climate change litigation is currently underway in more than a dozen jurisdictions and some of these cases are drawing considerable global attention. The extent to which the rights-based approach is used in those cases, however, may be different. So far, the most prominent case is Urgenda v. The Netherlands, which is an excellent example of employing the provisions of a national constitution to protect the climate. The plaintiffs successfully invoked Article 21 of the Dutch Constitution, which provides that "[i]t shall be the concern of the authorities to keep the country habitable and to protect and

\footnotetext{
${ }^{64}$ Ibid., see fn. 3.

65 Juliana v. United States, 217 F.Supp.3d 1224 (D. Or. 2016).

${ }^{66}$ Ibid., at 1234.

${ }^{67}$ Ibid., at 1233 .

${ }^{68}$ Ibid., at 1234.

${ }^{69}$ Among other things, the plaintiffs based their arguments on the Due Process Clause of the Fifth Amendment to the US Constitution, barring the federal government from depriving a person of "life, liberty, or property" without "due process of law." According to the plaintiffs, this violation resulted from the defendants' lax climate policy, favouring the fossil fuel industry. Ibid., at 1248,

${ }^{70}$ Ibid., at 1250 .
} 
improve the environment". ${ }^{71}$ The Hague District Court was persuaded that the state had a constitutional obligation to take stronger measures to mitigate climate change. It ordered the state "to limit the joint volume of Dutch annual greenhouse gas emissions, or have them limited, so that this volume will have reduced by at least twenty five per cent at the end of 2020 compared to the level of the year 1990". ${ }^{72}$ And while the case primarily revolved around the interpretation of the duty of care, the human rights dimension invoked by the plaintiffs (namely, Articles 2 and 8 of the European Convention on Human Rights) ${ }^{73}$ also played an important role in the court's analysis, and was "applied as an interpretative tool that assisted the Court in reaching its ultimate finding regarding the existence of a relevant duty of care and its breach". ${ }^{74}$ The Hague Court of Appeal upheld the District Court's ruling, concluding that the State's failure to pursue a more ambitious GHG reduction is unlawful, as it contravenes the duty of care under the abovementioned articles of the European Convention on Human Rights. ${ }^{75}$

Apart from the Urgenda case, there is a number of other cases in which petitioners have raised human rights claims, albeit with mixed success. For example, in the Pakistani case Leghariv. Pakistan, the human rights claims were central, with the plaintiff successfully alleging the government's violation of his constitutional rights to life and dignity, enshrined in Pakistan's Constitution by delaying the implementation of the National Climate Change Policy and failing to address vulnerabilities associated with climate change. ${ }^{76}$ Similarly, human rights claims were at the core of the Colombian case Future Generations v. Ministry of the Environment, where plaintiffs successfully invoked constitutionally recognized rights to a healthy environment, life, health, food, and water in challenging the government's inaction with regard to deforestation in the Amazon region, that, according to the plaintiffs, greatly contributed to the total volume of GHG emissions in the country and therefore, climate change. ${ }^{77}$ In this case, the constitutional right to a clean and healthy environment was instrumental in plaintiffs' success.

\footnotetext{
${ }^{71}$ Urgenda Foundation v. The State of the Netherlands, C/09/456689 / ha za13-1396 (the Hague District Court, 2015), <https://uitspraken.rechtspraak.nl/inziendocument?id=ECLI:NL:RBDHA:2015:7196> para. 2.69.

${ }^{72}$ Ibid., para. 5.1. It is worth mentioning that throughout its decision, the court had to operate within the complex synthesis of Dutch constitutional and civil law, international climate and human rights law, EU law and the scientific data provided by the IPCC.

${ }^{73}$ The human rights mechanisms invoked in this case, thus, pertain to international human rights law.

74 Jacqueline Peel and Hari M. Osofsky, A Rights Turn in Climate Change Litigation?, Transnational Environmental Law 7.1 (2018): 50. According to the court, Urgenda itself could not be designated as a direct or indirect victim of a violation of articles 2 and 8 within the meaning of the Convention; however, both articles and their interpretation given by the European Court of Human Rights, particularly with respect to environmental right issues, can serve as a source of interpretation when detailing and implementing open private-law standards, such as the unwritten standard of care (paras 4.45-4.46).

${ }^{75}$ The State of the Netherlands v Urgenda Foundation, The Hague Court of Appeal (9 October 2018), case 200.178.245/01 < https://uitspraken.rechtspraak.nl/inziendocument?id=ECLI:NL:GHDHA:2018:2610> para. 76.

${ }^{76}$ Lahore High Court in Ashgar Leghari v. Federation of Pakistan, w.p. No. 25501/2015 (2015) (the two Court orders are available at <https://elaw.org/system/files/pk.leghari.091415_0.pdf> and <https://elaw.org/system/files/pk.leghari.090415_0.pdf>), at 6.

${ }^{77}$ Future Generations v. Ministry of the Environment, STC4360 (2018) <http://blogs2.law.columbia.edu/climatechange-litigation/wp-content/uploads/sites/16/non-us-case-documents/2018/20180405_11001-22-03-000-2018-
} 
Meantime, while not central to the plaintiffs' claims, human rights were also invoked in Austrian $^{78}$ and South African ${ }^{79}$ climate cases. Both cases revolved around environmental impact assessment, yet both featured rights claims - a constitutional right to a clean and healthy environment in the latter case and a combination of European Union (EU) primary law concerning human rights (namely Article 37 of the Charter of Fundamental Rights, calling for a high level of environmental protection to be integrated into EU policies) and provisions of the national constitution establishing the principle of sustainability and comprehensive environmental protection in the former case. In both cases the courts used the above-mentioned provisions as interpretative tools. At the same time, plaintiffs in similar rights-based Irish $^{80}$ and Norwegian $^{81}$ climate lawsuits challenging governmental permits to activities resulting in GHG emissions were less successful, although in both cases the respective courts recognized the constitutional right to a clean and healthy environment that may well be the foundation for future litigation in these countries. ${ }^{82}$

Furthermore, considering the growing importance of internationalization in climate change litigation, sooner or later, the issue of climate change and human rights will likely have to be addressed not only by national, but also by international courts. To some extent, this has already happened: for instance, the recent advisory opinion issued by the Inter-American Court of

00319-00_decision.pdf>. Similar to the Urgenda case, the plaintiffs did not suffer direct harm derived from the deforestation of the Amazon region. Instead, they argued that an omission by the authorities led to this problem.

78 In re Vienna-Schwechat Airport Expansion, <http://blogs2.law.columbia.edu/climate-change-litigation/wpcontent/uploads/sites/16/non-us-case-documents/2017/20170202_W109-2000179-1291E_decision-3.pdf>.

79 EarthLife Africa Johannesburg v. Minister of Environmental Affairs and Others, <http://blogs2.law.columbia.edu/climate-change-litigation/wp-content/uploads/sites/16/non-us-casedocuments/2017/20170306_Case-no.-6566216_judgment.pdf>.

${ }^{80}$ Friends of the Irish Environment CLG v. Fingal County Council, <http://blogs2.law.columbia.edu/climatechange-litigation/wp-content/uploads/sites/16/non-us-case-documents/2017/20171121_2017-No.344-

JR_judgment.pdf>.

${ }_{81}$ Greenpeace Nordic Ass'n and Nature and Youth v. Ministry of Petroleum and Energy, $<$ http://blogs2.law.columbia.edu/climate-change-litigation/wp-content/uploads/sites/16/non-us-casedocuments/2018/20180104_16-166674TVI-OTIR06_judgment-2.pdf>.

${ }^{82}$ For example, in the Norwegian case, the parties have agreed that both environmental harm in a narrow sense and climate deterioration are covered by the Article 112 of the Norwegian constitution, which provides that:

Every person has the right to an environment that is conducive to health and to a natural environment whose productivity and diversity are maintained. Natural resources shall be managed on the basis of comprehensive long -term considerations which will safeguard this right for future generations as well.

In order to safeguard their right in accordance with the foregoing paragraph, citizens are entitled to information on the state of the natural environment and on the effects of any encroachment on nature that is planned or carried out.

Meanwhile, in Ireland, the court went even further in its interpretation of the right in question, stating that "A right to an environment that is consistent with the human dignity and well-being of citizens at large is an essential condition for the fulfilment of all human rights. It is an indispensable existential right that is enjoyed universally, yet which is vested personally as a right that presents and can be seen always to have presented, and to enjoy protection, under [...] the Constitution. It is not so utopian a right that it can never be enforced. Once concretised into specific duties and obligations, its enforcement is entirely practicable." 
Human Rights has found that the right to a healthy environment is a human right $^{83}$ and specifically recognized the adverse effect of climate change on human rights. ${ }^{84}$ This advisory opinion emphasized the interdependence and indivisibility between human rights, the environment and sustainable development, since the full enjoyment of all human rights depends on a favorable environment. ${ }^{85}$ Even more so, the Court stressed that numerous human rights protection systems recognize the right to a healthy environment as a right in itself, although it expressed no doubt that other human rights are also vulnerable because of environmental degradation, which prompts a series of environmental obligations for governments to ensure that they comply with their duties to respect and ensure those rights.

Finally, one might remember the dissenting opinion of judge ad hoc Dugard in the International Court of Justice case Costa Rica v. Nicaragua issued in early 2018 and concerning the compensation owed by Nicaragua to Costa Rica. ${ }^{86}$ A part of that opinion specifically addressed the question of climate change liability resulting from deforestation, referring to the Paris Agreement and going as far as stating that "the obligation not to engage in wrongful deforestation that results in the release of carbon into the atmosphere and the loss of gas sequestration services is certainly an obligation erga omnes"; in other words, implying that the issue of climate change mitigation and, accordingly, state liability, is a matter of concern to the international community as a whole.

\section{Concluding remarks}

While international climate negotiations and domestic climate policies continue to be the main pillar of climate policy, litigation has played a significant role in shaping the contemporary climate change law. Following the initial and isolated attempts to fill in the regulatory gaps left by the policymakers, litigation has significantly expanded and enriched from a diverse spectrum of legal theories used by the parties over the last several years. Time will tell whether the legal mechanism analysed above proves instrumental in the long run; for now, at least, this scenario does not seem to be unrealistic. Although the discussed litigation pertains to a specific area of climate change law, it has already demonstrated a potentially broader reach and interaction with other areas. That said, it also has to be acknowledged that there are certain challenges when

\footnotetext{
${ }^{83}$ Under the Inter-American human rights system, the right to a healthy environment is recognized explicitly in Article 11 of the San Salvador Protocol: 1) Everyone shall have the right to live in a healthy environment and to have access to basic public services; 2) The States Parties shall promote the protection, preservation, and improvement of the environment.

${ }^{84}$ The Environment and Human Rights (State Obligations in Relation to the Environment in the Context of the Protection and Guarantee of the Rights to Life and to Personal Integrity - Interpretation and Scope of Articles 4(1) and 5(1) of the American Convention on Human Rights), Advisory Opinion OC-23/18, Inter-Am. Ct. H.R., (ser. A) No. 23 (Nov. 15, 2017), <http://www.corteidh.or.cr/docs/opiniones/seriea_23_esp.pdf> (in Spanish).

${ }^{85}$ For a discussion on the potential role of this advisory opinion see Christopher Campbell-Duruflé and Sumudu Anopama Atapattu, The Inter-American Court's Environment and Human Rights Advisory Opinion: Implications for International Climate Law, Climate Law 8.3-4 (2018): 321-337.

${ }^{86}$ Certain Activities Carried out by Nicaragua in the Border Area (Costa Rica v. Nicar.), compensation owed by the Republic of Nicaragua to the Republic of Costa Rica, General List No. 150, at para. 42 (Int'1 Ct. Just. Feb. 2, 2018), dissenting opinion of Judge Ad Hoc Dugard.
} 
assessing the overall relevance of case-law within different jurisdictions and the potential transposition of experience from one jurisdiction into others. For instance, different procedural requirements related to standing, etc., may play a decisive role in determining whether a case in any given jurisdiction can be successful or not. ${ }^{87}$ But ultimately, the ingenuity of scholars and practitioners searching for the most effective legal strategies might be viewed as a sign of constant progress which permeates the entire field of climate change law.

${ }^{87}$ See, for example, Samvel Varvastian, Access to Justice in Climate Change Litigation from a Transnational Perspective: Private Party Standing in Recent Climate Cases, in J. Jendrośka and M. Bar (eds), Procedural Environmental Rights: Principle $X$ of the Rio Declaration in Theory and Practice (Cambridge: Intersentia, 2017); Dinah Shelton, Complexities and Uncertainties in Matters of Human Rights and the Environment: Identifying the Judicial Role, in John H. Knox and Ramin Pejan (eds.), The Human Right to a Healthy Environment (Cambridge: Cambridge University Press, 2018). 
Cover: Imbalanced World, 1996, Veronika Dell‘Olio (photo: Miriam Aziz)

"Essential to our concept was the establishment of a connection to the work and objectives of the institute. In view of the diversity of the research tasks concerned, we have attempted to highlight an overarching idea that can be understood as the institute's mission. We see this as the ideal of peaceful relations between peoples on the basis of an internationally validated notion of justice.... The depicted sculpture...[symbolizes] an imbalanced world in which some peoples are oppressed while others lay claim to dominance and power. The honeycomb form of the circular disks denotes the [international] state structure. Glass parts ... [represent] the individual states .... [The division] of the figure ... into two parts [can] be interpreted as the separation of the earth into two unequal worlds. The scissors-shaped base, on the one hand, makes the gap between them clear, on the other hand, a converging movement of the disks is conceivable... The sculpture [aims] at what is imagined - the possibility of the rapprochement of the two worlds." [transl. by S. Less]

Art in architecture, MPIL, Heidelberg

\section{MAX PLANCK INSTITUTE}

FOR COMPARATIVE PUBLIC LAW

AND INTERNATIONAL LAW

Im Neuenheimer Feld 535

D-69120 Heidelberg

Tel.: +49 (0)6221 $482-1$

Fax: $+49(0) 6221482-288$

www.mpil.de

SSRN@mpil.de 